\title{
Penanaman Nilai-nilai Kepedulian terhadap Kebersihan Lingkungan pada Siswa Kelas III di Sekolah Alam Mahira Kota Bengkulu
}

\author{
Evita Sangkut \\ Universitas Bengkulu \\ evitasangkut97@gmail.com \\ Puspa Djuwita \\ Universitas Bengkulu \\ puspadjuwita58@gmail.com \\ Dalifa \\ Universitas Bengkulu \\ dalifa.abdullah@gmail.com
}

\begin{abstract}
This study aims to describe "The cultivation of values of Concern on Environmental Hygiene in Students Class III A At the Elementary School of Nature Mahira Bengkulu City". This type of research is using qualitative and qualitative descriptive research method. Research subjects were principal, grade III A teacher, janitor, canteen mother, and third grade student $A$. Data collection technique used was observation, interview, and documentation. The analysis technique is carried out during field analysis and post-field analysis by examining all data collected in narrative. The data that have been obtained is analyzed by data reduction, data presentation, and conclusion. The data credibility test is done through increasing persistence and triangulation of sources and techniques. The results obtained are: a) The strategy of cultivating the values of caring is done by habituation, exemplary and menjarkan about cleanliness; b) Program activities are: clean culture, clean saturation program, class cleanliness, school environment cleanliness, and waste management; c) Facilities and infrastructure; d) School community support: principals, janitors, and canteen mothers.
\end{abstract}

Keywords: Cultivation of Values, care, Hygiene of school environment

\begin{abstract}
Abstrak
Penelitian ini bertujuan untuk mendeskripsikan "Budidaya nilai-nilai Kepedulian terhadap Kebersihan Lingkungan pada Siswa Kelas III A di Sekolah Dasar Alam Mahira Kota Bengkulu". Jenis penelitian ini menggunakan metode penelitian deskriptif kualitatif dan kualitatif. Subjek penelitian adalah kepala sekolah, guru kelas III A, petugas kebersihan, ibu kantin, dan siswa kelas tiga A. Teknik pengumpulan data yang digunakan adalah observasi, wawancara, dan dokumentasi. Teknik analisis dilakukan selama analisis lapangan dan analisis pascalapangan dengan memeriksa semua data yang dikumpulkan dalam
\end{abstract}


narasi. Data yang telah diperoleh dianalisis dengan reduksi data, penyajian data, dan penarikan kesimpulan. Uji kredibilitas data dilakukan melalui peningkatan ketekunan dan triangulasi sumber dan teknik. Hasil yang diperoleh adalah: a) Strategi menumbuhkan nilainilai kepedulian dilakukan dengan pembiasaan, keteladanan dan menjarkan tentang kebersihan; b) Kegiatan program adalah: budaya bersih, program saturasi bersih, kebersihan kelas, kebersihan lingkungan sekolah, dan pengelolaan limbah; c) Fasilitas dan infrastruktur; d) Dukungan komunitas sekolah: kepala sekolah, petugas kebersihan, dan ibu kantin.

Kata kunci: Budidaya Nilai, peduli, Kebersihan lingkungan sekolah

\section{Pendahuluan}

Kebersihan lingkungan merupakan salah satu hal terpenting untuk menciptakan lingkungan yang nyaman dan tentram. Tentu saja bila lingkungan yang kumuh akan menjadikan orang enggan berlama lama karena mengangu kesehatan manusia secara fisik dan psikis untuk berada di lingkungan tersebut. Maka kebersihan lingkungan adalah harga mutlak untuk mewujudkan iklim yang nyaman, termasuk iklim lingkungan sekolah. Bagaimana mungkin siswa mampu menangkap pelajaran yang disampaikan dengan maksimal bila siswa itu sendiri kurang nyaman berada di kelas karena kotor. Belum lagi kamar mandi sekolah yang identik dengan bau dan kotor karena perilaku jorok para siswa. Adapun manfaat dari lingkungan bersih yaitu: kebersihan lingkungan sekolah menambah semangat siswa dalam belajar, kebersihan lingkungan menjadi keunggulan sekolah, kebersihan dapat melancarkan otak manusia, dan terhindar dari penyakit yang disebabkan oleh lingkungan yang tidak bersih.

Manusia perlu menjaga kebersihan lingkungan dan kebersihan diri agar tetap sehat dan tidak mudah terserang penyakit bagi diri sendiri maupun orang lain. Menurut Mundiatun dan Daryanto (2015: 37) ada banyak cara untuk menjaga kebersihan lingkungan, misalnya dengan membuang sampah pada tempatnya, selalu membersihkan selokan air, memisahkan sampah kering dan sampah basah, rajin membersihkan halaman sekolah, mendaur ulang barang yang tidak terpakai. Jika kita tidak menjaga kebersihan lingkungan maka lingkungan menjadi tidak sehat dan dapat menyebabkan penyakit.

Masalah lingkungan terus menjadi agenda pembicaraan secara global. Tentang pencemaran dan kerusakan lingkungan di muka bumi telah menjadi suatu hal yang menakutkan terhadap berkelanjutan kehidupan manusia. Lingkungan sendiri yang semestinya menjadi salah satu sumber kenikmatan dalam kehidupan. Kini telah menjadi sumber kegelisahan dan kecemasan. Namun ironisnya tak banyak yang tahu dan peduli dengan lingkungan.

Pada umumnya warga negara Indonesia kurang peduli terhadap lingkungan yang bersih salah satunya wilayah Bengkulu. Contohnya pada saat perayaan apapun itu, seperti perayaan tabut banyak sekali orang yang masih membuang sampah sembarangan kemudian pada saat sedekahan atau acara-acara besar yang diadakan di Pantai Bengkulu. Selesai acara banyak sekali sampah-sampah yang berserakan, ditepi pantai pun masih saja sampah berserakan akibat dari orang-orang yang kurang peduli terhadap lingkungan yang bersih, padahal pantai itu adalah tempat wisata yang indah, sejuk dan menyenangkan. Kemudian di sekolah masih ada siswasiswi yang kurang peduli terhadap lingkungan sekolah yang bersih. contohnya masih ada siswa yang membuang sampah sembarangan, seperti buang sampah di dalam laci bekas tisu, kertas, plastik-plastik kecil, dan lain sebagainya. Dan masih saja 
ditemukan anak-anak yang membuang air kecil sembarangan dan tidak di siramkan kembali setelah mereka buang air kecil. Akibatnya akan menjadi bau yang tidak sedap di lingkungan sekolah. terutama anak laki-laki yang keseringan tidak menyiramkan kembali WC setelah dipakai. jadi bukan hanya di sekolah yang harus kita peduli tentang kebersihan lingkungan, tetapi di alam sekitar kita perlu dipedulikan tentang lingkungan yang bersih agar selalu terjaga kebersihan dan kenyamanan bagi kita semua.

Peduli lingkungan bukanlah sepenuhnya talenta maupun instink bawaan, akan tetapi juga merupakan hasil dari suatu proses pendidikan dalam arti luas. Salah asuh atau salah didik terhadap seorang individu bisa jadi akan menghasilkan karakter yang kurang terpuji tehadap lingkungan. Karena itu prilaku yang baik haruslah dibentuk kepada setiap individu, sehingga setiap individu dapat menjiwai setiap tindakan dan perilakunya. Sementara kita memahami bahwa prilaku bukanlah semata-mata talenta bawaan individu, akan tetapi merupakan hasil bentukan manusia dan lingkungan tempat ia tinggal, hidup, dan dibesarkan. Dan bagaimana cara membentuk prilaku yang baik tersebut, secara akademis tentu jawabannya hanya satu, yaitu "pendidikan". Pendidikan memungkinkan untuk membentuk prilaku yang baik selaku manusia seperti yang diharapkan.

Untuk mengatasi masalah lingkungan yang tidak bersih diperlukan pendidikan kepedulian terhadap lingkungan Di mulai dari PAUD sampai perguruan tinggi (Wakhidah 2014: 39). Pendidikan peduli pada lingkungan sudah ada di dalam kurikulum sekolah sejak dulu. Hal ini terbukti dari adanya lembaga yang sudah menggunakan visi tentang kepedulian pada lingkungan atau cinta alam.

Anak-anak saat ini masih kurang peduli dengan kebersihan kelas dan lingkungan sekolah. Seringkali ditemukan siswa yang masih membuang sampah didalam laci dan membuang air kecil tidak disiramkan kembali hal tersebut menimbulkan bau yang tidak sedap dilingkungan sekolah. Menurut Widiasworo (2017: 225) mengemukakan rata-rata peserta didik saat ini kurang menyadari akan pentingnya menjaga kebersihan kelas. Mereka seolah-olah tidak peduli dengan kondisi kebersihan kelas maupun lingkungannya. Kebanyakan dari mereka berpikir, bahwa kebersihan kelas adalah tanggung jawab petugas piket dan petugas kebersihan sekolah. Mereka ikut menjaga kebersihan jika pada gilirannya mendapat tugas piket sesuai jadwal, atau saat dilaksanakan kerja bakti membersihkan lingkungan kelas dan sekolah.

Padahal suasana kelas yang kotor, bau, dengan penataan bangku dan sarana yang ada dalam kelas tidak rapi, akan membuat suasana menjadi tidak nyaman. Jika lingkungan kelas saja tidak nyaman bagi peserta didik, otomatis mereka tidak akan dapat fokus belajar. Akibatnya, kegiatan pembelajaran menjadi terganggu karena tidak dapat berlangsung secara efektif sesuai dengan yang diharapkan. Hal ini sangat berpengaruh pada prestasi belajar peserta didik nantinnya.

Sekolah Alam Mahira Bengkulu adalah satu-satunya Sekolah Islam di Bengkulu yang menerapkan konsep Alam sekaligus Sekolah Alam Pertama yang ada di provinsi Bengkulu. Di Sekolah Alam Mahira Bengkulu ini tidak dikenal yang namanya gedung sekolah bertingkat, lantai tegel putih, ruang kelas yang dilengkapi dengan penyejuk ruangan (AC) dan lain sebagainya. Disini anak-anak justru belajar di saung-saung dengan atap rumbia. Ruang kelas pun tidak dihias dengan dengan indah seperti yang banyak dilakukan oleh sekolah sekolah formal lainnya. Justru aneka ragam barang yang sudah tidak layak pakai (barang bekas) bagi sebagian orang bisa menjadi dekorasi kelas di alam terbuka. 
Berdasarkan hasil wawancara yang dilakukan saat pra penelitian (Februari 03 2018) di Sekolah Dasar Alam Mahira Kota Bengkulu. Melihat lingkungan sekolah yang bersih, terawat dan banyak pohon-pohon di halaman sekolah. Sekolah alam ini menerapkan lingkungan yang mendidik siswa-siswinya, baik itu proses pembelajarannya, peraturannya, dan sebagainya. Di Sekolah Dasar Alam Mahira ini siswa-siswinya mulai terlihat nilai kepeduliannya terhadap kebersihan lingkungan, dan di sekolah alam ini sudah di biasakan sesudah sholat dzuhur siswa-siswinya keliling lingkungan sekolah untuk mengambil sampah-sampah yang masih ada di sekitar sekolah dan membuang sampah pada tempatnya mulai dari jam 01.00-01.15 itu dinamakan mahira bebas sampah. Mahira bebas sampah ini memang sudah jadi program dari pihak sekolah jadi dilakukan setiap hari selesai sholat dzuhur waktunya selama lima belas menit. Selain itu memang sudah ada petugas kebersihan setiap sorenya. Berdasarkan uraian fenomena di atas maka peneliti tertarik untuk melakukan penelitian yang membahas dan mendeskripsikan tentang penanaman nilai-nilai kepedulian terhadap kebersihan lingkungan di Sekolah Dasar Alam Mahira Kota Bengkulu. Untuk mengetahui hal tersebut, peneliti menggunakan jenis penelitian deskriptif yaitu penelitian untuk memaparkan atau menggambarkan suatu hal. Maka dari itu peneliti tertarik untuk melakukan penelitian dengan mengangkat judul "Studi Deskriptif Penanaman Nilai-Nilai Kepedulian Terhadap Kebersihan Lingkungan Pada Siswa Kelas III Di Sekolah Dasar Alam Mahira Kota Bengkulu". Tujuannya supaya hasil penelitian ini menjadi model bagi sekolah-sekolah yang lain bagaimana cara penanaman nilai-nilai kepedulian terhadap kebersihan lingkungan sekolah.

\section{Metode}

Jenis penelitian ini adalah kualitatif, dengan metode yang digunakan analisis deskriptif sesuai dengan tujuan penelitian yaitu untuk mendeskripsikan bagaimana sekolah menanamkan nilai-nilai kepedulian lingkungan yang bersih pada siswa kelas III A Sekolah Dasar Alam Mahira Kota Bengkulu.

Subjek dalam penelitian ini adalah Kepala sekolah, ibu kantin, petugas kebersihan, Guru kelas III A dan siswa kelas III A Sekolah Dasar Alam Mahira Kota Bengkulu.

Dalam penelitian ini yang menjadi instrumen penelitian adalah peneliti sendiri. Sebagai instrumen utama dalam penelitian, peneliti juga menggunakan instrumen pendukung yang dibutuhkan peneliti selama mengumpulkan data yaitu berupa pedoman observasi dan pedoman wawancara. Adapun kisi-kisi yang dijadikan sebagai pedoman observasi dan pedoman wawancara dalam penelitian ini adalah sebagai berikut.

Tabel Indikator Penanaman Nilai-Nilai Kepedulian terhadap Kebersihan Lingkungan pada Siswa Kelas III di Sekolah Dasar Alam Mahira Kota Bengkulu

$\begin{array}{lllll}\text { Fokus } & \text { Sub fokus } & \text { Aspek yang } & \text { Subjek } & \text { Alat data }\end{array}$
diamati

\begin{tabular}{|c|c|c|c|c|}
\hline $\begin{array}{l}\text { Penanaman } \\
\text { Nilai-Nilai } \\
\text { Kepedulian } \\
\text { Terhadap } \\
\text { Kebersihan } \\
\text { Lingkungan }\end{array}$ & $\begin{array}{l}\text { 1. Strategi } \\
\text { penanaman } \\
\text { nilai-nilai } \\
\text { kepedulian } \\
\text { terhadap } \\
\text { kebersihan } \\
\text { lingkungan }\end{array}$ & $\begin{array}{ll}\text { 1. } & \text { Melalui } \\
\text { pembiasaan }\end{array}$ & $\begin{array}{ll}\text { 1. } & \text { Kepala } \\
& \text { sekolah } \\
\text { 2. } & \text { Guru } \\
\text { 3. Siswa } \\
\text { 4. Ibu kantin } \\
\text { 5. Petugas } \\
\text { kebersihan }\end{array}$ & $\begin{array}{ll}\text { 1. } & \text { Observasi } \\
\text { 2. Wawancara } \\
\text { 3. } \\
\text { si }\end{array}$ \\
\hline
\end{tabular}




\begin{tabular}{|c|c|}
\hline $\begin{array}{l}\text { 2. Program- } \\
\text { program } \\
\text { kegiatan } \\
\text { dari pihak } \\
\text { sekolah }\end{array}$ & $\begin{array}{l}\text { 1. } \begin{array}{l}\text { Melalui budaya } \\
\text { bersih }\end{array} \\
\text { 2. Program sabtu } \\
\text { bersih } \\
\text { 3. Melalui } \\
\text { kebersihan dan } \\
\text { kelas kebersihan } \\
\text { lingkungan } \\
\text { sekolah } \\
\text { Melalui } \\
\text { pengelolaan } \\
\text { sampah }\end{array}$ \\
\hline $\begin{array}{l}\text { 3. Sarana dan } \\
\text { prasarana } \\
\text { dari pihak } \\
\text { sekolah }\end{array}$ & $\begin{array}{l}\text { 1. Sarana yang di } \\
\text { sediakan } \\
\text { 2. Prasarana yang } \\
\text { disediakan }\end{array}$ \\
\hline $\begin{array}{l}\text { 4.Dukungan } \\
\text { masyarakat } \\
\text { sekolah } \\
\text { terhadap } \\
\text { penanaman } \\
\text { nilai-nilai } \\
\text { kepedulian }\end{array}$ & $\begin{array}{l}\text { 1. Dukungan dari } \\
\text { petugas } \\
\text { kebersihan } \\
\text { 2. Dukungan dari } \\
\text { kepala sekolah } \\
\text { 3. Dukungan dari } \\
\text { ibu kantin }\end{array}$ \\
\hline & $\begin{array}{ll}\text { 4. Dari pihak } \\
\text { sekolah } \\
\text { memberikan } \\
\text { penghargaan } \\
\text { pada siswa } \\
\text { yang rajin dan } \\
\text { bersih } & \\
\text { 5. } & \text { Dari } \quad \text { warga } \\
\text { sekolah } & \text { sanksi } \\
\text { apa } & \text { jika } \\
\text { ditemukan } & \\
\text { siswa } & \text { yang } \\
\text { tidak } & \\
\text { melaksanakan } & \text { piket }\end{array}$ \\
\hline
\end{tabular}

Teknik pengumpulan data yang digunakan yaitu observasi, wawancara dan dokumentasi. Melalui observasi, data dikumpulkan dengan mengamati kegiatan pembelajaran di dalam kelas dan kegiatan di luar kelas. Jenis obervasi yang digunakan adalah observasi non partisipan (participatory observation) dimana dalam observasi ini peneliti tidak ikut serta dalam kegiatan. Jenis wawancara yang digunakan yaitu semi terstruktur. Di mana peneliti menanyakan berbagai pertanyaan yang sudah terstruktur, kemudian satu per satu diperdalam untuk mengorek keterangan lebih lanjut. Dengan demikian jawaban yang diperoleh bisa meliputi semua variabel, dengan keterangan yang lebih lengkap dan mendalam (Arikunto, S, 2012: 270). Sedangkan data yang dikumpulkan melalui dokumentasi berupa jadwal program-program kegiatan kebersihan dan profil SD Alam Mahira Kota Bengkulu.

Teknik analisis data dilakukan dengan menelaah seluruh data yang didapatkan dari hasil observasi, wawancara dan hasil dokumentasi. Selanjutnya data yang diperoleh 
dianalisis mulai dari pengumpulan data, reduksi data, penyajian data dan penarikan kesimpulan.

\section{Hasil}

\section{Strategi penanaman nilai-nilai kepedulian}

1) melalui pembiasaan

Berdasarkan hasil pengamatan didapatkan, bahwa pembiasaan di SD Alam Mahira Bengkulu yang dilakukan setiap hari yaitu membuang sampah pada tempatnya, piket kelas dilakukan setiap hari dan setiap kelas sudah ada jadwal piket masingmasing yang ditempelkan di dinding kelas. Setiap anak sudah memiliki tanggung jawab sendiri untuk piket kelas. pembiasaan sebelum masuk kelas yaitu alas kaki dilepas, meyusun meja pada saat mau belajar dan merapikan kembali meja selesai pembelajaran.

2) melalui keteladanan

Berdasarkan hasil pengamatan di dapatkan, bahwa guru (ummi) memberikan cotoh hal-hal yang menunjukkan kebersihan jika ada sampah. Ummi mengambil terlebih dahulu dan jika kelas kotor ummi menyapu kelas, karena anak kelas III masih perlu sekali bimbingan dalam segi kebersihan karena mereka saja menyapu masih belum bersih.

3) melalui mengajarkan tentang kebersihan

Berdasarkan hasil pengamatan didapatkan, bahwa guru di SD Alam Mahira Bengkulu sangat disiplin dalam megarahkan anak-anak untuk menciptakan linkungan yang bersih dan nyaman. Guru selalu mengarahkan pada muridmuridnya saat belajar di kelas tidak boleh pakai sendal atau sepatu nanti kelasnya kotor. Sendal-sendal pun dilepas dan disusun rapi di depan kelas. Guru pun mengajarkan kepada anak-anak pentingnya kebersihan, manfaat dari kebersihan, dan kebersihan juga sebagian dari iman.

\section{Program-program kegiatan}

1) program budaya bersih

Budaya bersih yang dilakukan di SD Alam Mahira Bengkulu dengan adanya jadwal piket kelas, jadwal piket WC, mahira bebas sampah yang dilakukan setiap hari setelah sholat dzuhur, kebersihan sebulan sekali yang dilakukan untuk kebersihan lingkungan sekolah, dan sabtu bersih yang di lakukan satu minggu sekali itu tepatnya hari sabtu sudah senam pagi langsung kebersihan dalam ruangan kelas dan sekitar kelas depan dan belakang kelas.

2) program sabtu bersih

Dari hasil pengamatan setiap hari sabtu selesai senam anak-anak langsung kebersihan. Semua kelas melakukan senam terlebih dahulu yang dimulai dari pukul 07.30-08.00. kemudian anak-anak kelas III A masuk ke kelas melakukan buka kelas yang dimulai dari pukul 08.00-08.30 dengan melakukan sholat dhuha, mengaji dan tausiyah yang disampaikan oleh guru. Kemudian langsung dilanjutkan dengan kebersihan dari pukul 08.30-09.00. Sebelum mulai kebersihan anak-anak diarahkan terlebih dahulu atau diingatkan kembali. Kemudian guru membagikan tugas kepada anak-anak, ada yang membersihkan di dalam kelas, membersihkan depan kelas, membersihkan belakang kelas, dan samping kelas.

3) kebersihan lingkungan sekolah

Berdasarkan pengamatan yang peneliti lakukan untuk kebersihan ligkungan sekolah selain warga sekolah ada petugas kebersihan. petugas tersebut berkewajiban membersihkan lingkungan sekolah di tempat-tempat yang tertentu seperti taman atas didekat kantor, halaman atas dan ruang-ruangan kantor. Mereka 
melakukannya pada saat pagi hari pukul 05.30 mereka sudah mulai bekerja dan sore hari pukul 05.00.

4) pengelolaan sampah

Berdasarkan pengamatan di SD Alam Mahira Bengkulu untuk pengelolaan sampahnya di bakar, pada saat ini untuk pembedaan antara sampah organik dan sampah anorganik masih belum stabil, karena koordinator bagian bank sampah sudah pindah tugas jadi belum ada pengganti bagian bank sampah. Di SD Alam Mahira sudah disediakan dua kotak sampah yang diberi nama organik dan anorganik setiap kelas, namun anak-anak masih belum bisa membedakan masih saja tercampur.

\section{Sarana dan prasarana dari pihak sekolah}

1) sarana

Berdasarkan pengamatan jenis alat-alat kebersihan yang disediakan di SD Alam seperti: sapu, kain pel, ember, kotak sampah, kemoceng, serokan, sabun cuci tangan, sabun WC, penyikat WC, cangkul, sabit. Pemanfaatannya sapu untuk menyapu didalam kelas dan di depan kelas, sapu lidi untuk menyapu di sekitar kelas dan lingkungan sekolah. Kondisi alat-alat kebersihannya masih bagus dan masih lengkap, namun slogan tentang kebersihan yang masih kurang. Pengadaan alat-alat kebersihan di SD Alam Mahira dari pihak sekolah, alat-alat kebersihan yang sudah di beli kemudian dibagikan oleh pihak sekolah ke kelas masing-masing.

\section{2) prasarana}

Berdasarkan pengamatan di SD Alam Mahira Bengkulu Prasarana berarti bangunbangunan di sekolah Alam. di sini yang dijelaskan tentang prasarana yang mencakup tentang bangunan seperti WC, tempat cuci tangan, tempat pembuangan sampah, tempat aliran air kotor. di SD Alam Mahira Bengkulu terdapat 6 WC siswasiswi terdiri dari $3 \mathrm{WC}$ perempuan, $3 \mathrm{WC}$ laki-laki, dan $4 \mathrm{WC}$ guru terdiri dari $2 \mathrm{WC}$ Guru laki-laki, 2 WC Ibu guru. Tempat pembuangan sampah ada 1 di lapangan bawah, tempat cuci tangan terdapat 4 tempat di bawah dekat kelas III ada 2 dan di atas dekat kantor ada 2 namun biasanya digunakan untuk mengambil air wudhu.

\section{Dukungan masyarakat sekolah}

1) dukungan dari petugas kebersihan

Berdasarkan pengamatan yang peneliti lakukan bahwa bentuk dukungan yang terlihat di SD Alam Mahira Bengkulu ialah dengan adanya kebersihan setiap hari yang dilakukan pada saat pagi dan sore hari oleh petugas penjaga kebersihan dan terlihat juga petugas kebersihan selalu mengingatkan kepada anak-anak untuk tidak buang sampah sembarangan.

2) dukungan dari kepala sekolah

Berdasarkan pengamatan yang peneliti lakukan bahwa bentuk dukungan yang terlihat di SD Alam Mahira Bengkulu ialah kepala sekolah mengajak dan memotivasi anak-anak untuk selalu menjaga kebersihan dan dari pihak sekolah menyediakan fasilitas kebersihan agar anak-anak selalu semangat untuk melakukan kebersihan setiap harinya.

3) dukungan dari ibu kantin

Berdasarkan pengamatan selama peneliti lakukan didapatkan hasil bahwa dukungan dari ibu kanti selalu mengatakan kepada anak-anaknya supaya tidak membuang sampah sembarangan, kalau jajan jangan sembarangan. Dan ketika sudah jajan sampahnya di buang pada tempatnya karena di depan kantin sudah tersedia dua kotak sampah.

\section{Pembahasan}


Pembiasan yang ditanamkan kepada anak-anak mengenai kebersihan yaitu piket kelas setiap hari, dengan melakukan hal seperti: menyapu, menghapuskan papan tulis, membuang sampah pada tempatnya, cuci tangan sebelum makan. Dalam kegiatan pembelajaran di SD Alam Mahira mengembangkan konsep berbasis alam. Ruang kelas tempat belajarnya pun berbeda. Meja yang digunakan untuk belajar akan disusun ketika kegiatan pembelajaran dimulai dan dirapikan kembali ketika pembelajaran selesai. Pada saat masuk kelas anak-anak dibiasakan melepas alas kaki kemudian di susun rapi di depan kelas, agar kelas tidak kotor dan tetap bersih. Ada juga pembiasaan seminggu sekali setiap hari Rabu membersihkan WC dan setiap hari Sabtu bersih-bersih kelas dan lingkungan sekolah. Hal ini sesuai dengan hasil penelitian (Anwari, 2014: 238) Cara yang dilakukan melalui pembiasaan adanya kegiatan rutin harian, mingguan dan sewaktu-waktu.

Guru memberi contoh selalu ikut serta dalam hal kebersihan. Secara tidak langsung guru memberi teladan kepada anak-anak dengan baik. Kemudian anak-anak menuruti apa yang dilakukan oleh guru. Guru membimbing anak-anak pada saat piket kelas, jika guru melihat sampah, sampahnya diambil dan dibuang pada tempatnya. Setiap masuk ke kelas dan siap mau belajar guru mengecek terlebih dahulu kebersihan kelas. kemudian teladan dari ibu kantin selalu menegur anakanak untuk membuang sampah pada tempatnya. Hal ini sesuai dengan hasil penelitian (Wakhidah, 2014: 43) mencotohkan untuk membuang sampah sesuai dengan tempatnya. Sehingga secara tidak langsung mengajarkan kepada anak-anak untuk membuang sampah pada tempatnya. Hal ini didukung Depdiknas, teladan adalah kegiatan yang dilakukan dengan memberikan teladan dengan baik kepada anak.

Diajarkan bahwa pentingnya kebersihan, manfaat kebersihan, jika membuang sampah jangan sembarangan, setelah belajar mejanya di rapikan kembali, jangan mencoret tembok dan meja. Guru selalu mengajak atau memotivasi siswa dengan memberikan pujian-pujian, seperti: "siapa yang bersih dan rapi cepat pulangnya" jadi semua anak-anak bersemangat dan berlomba-lomba untuk membersikan kelas. Hal ini sesuai dengan pendapat Widiasworo (2017: 233) menyadarkan peserta didik akan pentingnya menjaga kebersihan kelas, mencermati petugas piket kebersihan, apakah telah bekerja secara maksimal sesuai dengan tugasnya atau belum jika belum, guru perlu mengingatkan dan mengoptimalkan kerja mereka, melarang peserta didik membuang sampah secara sembarangan di kelas, melarang peserta didik mencoret-coret meja atau kursi dalam kelas.

Budaya bersih di SD Alam Mahira meliputi jadwal piket kelas, tata tertib tentang kebersihan, jadwal piket WC, mahira bebas sampah yang dilakukan setiap hari setelah sholat dzuhur, kebersihan sebulan sekali yang dilakukan untuk kebersihan lingkungan sekolah, dan sabtu bersih yang dilakukan satu minggu sekali itu tepatnya hari sabtu setelah senam pagi langsung kebersihan dalam ruangan kelas dan sekitar kelas, depan dan belakang kelas. Dengan adanya program budaya bersih di SD Alam Mahira selalu terjaga kebersihannya dan jauh dari bau yang tidak sedap. Hal ini sesuai dengan pendapat Kompri (2014: 331) cara yang dapat dilakukan guru pada pencegahan kerusakan lingkungan sangat diperlukan tindakan-tindakan yang berupa membuat tata tertib kebersihan; piket kelas; memberi contoh membuang sampah pada tempatnya; memberikan nasehat apabila ditemukan pelanggaran membuang sampah sembarangan; memberikan reward kepada petugas piket yang rajin, bersih dalam membersikan kelasnya; membiasakan diri cuci tangan sehinga murid juga meniru.

Program sabtu bersih dilakukan seusai senam pagi kemudian guru membagikan tugas kepada anak-anak, ada yang membersihkan di dalam ruangan kelas, ada 
sebagian mebersihkan depan kelas, mencabut rumput dan memungut sampah lalu membuang sampah pada tempatnya. Ketika belajar, mereka menggunakan alas duduk seperti tikar, jadi anak-anak harus membersihkan tikar terlebih dahulu sebelum pembelajaran di mulai karena kebersihan dan keindahan ruang kelas serta sekolah menjadi tanggung jawab warga sekolah. Hal ini sesuali dengan hasil penelitian (Anwari 2014: 242) kegiatan sabtu bersih ini dilakukan dalam rangka bersih-bersih ruang kelas dan lingkungan sekolah.

Pengelolaan sampahnya di SD Alam Mahira dibuang pada tempat pembuangan akhir dilapangan bawah kemudian di bakar, dan pada saat ini pembedaan antara sampah organik dan sampah anorganik masih belum stabil, dikarenakan tidak ada lagi yang mengkoordinator bagian pengelolaan sampah. sekarang pengurus bank sampah sudah pindah dan belum ditentukan kembali siapa pengantinya. Pada saat masih ada pengurusnya sampahnya dipisahkan antara organik dan anorganik dan dipilah ada sebagian botol bekas yang dijadikan pot bunga. Hal ini sesuai dengan pendapat Kompri (2014: 336) tahapan-tahapan pengelolaan sampah di sekolah adalah a) pencegah dan pengurangan sampah dari sumbernya.

Kondisi sarana di SD Alam Mahira Bengkulu masih layak dan peralatan yang digunakan untuk kebersihan lengkap dan digunakan. Dari pihak sekolah sudah menyediakan lengkap peralatan kebersihan seperti kotak sampah, sapu, sapu lidi, kemojeng, serokan, sabit, sabun, cangkul. Kotak sampah untuk setiap kelas diberikan 2, bahkan ada yang 3 kotak sampah. Kotak sampah yang di sediakan pihak sekolah memanfaatkan barang bekas, yakni ember bekas cat kemudian ditulis organik dan anorganik. Namun anak-anak masih susah untuk membedakan antara sampah organik dan sampah anorganik, jadi masih tercampur antara sampah basah dan sampah kering. Prasarana yang di sediakan yaitu air bersih, tempat cuci tangan, toilet, tempat pembuangan sampah, dan prasarana yang lainnya yang disebut adalah prasana bagian kebersihan. Hal ini sesuai dengan pendapat (Samani, 2011: 147) penciptaan kondisi toilet yang bersih, disediakan tempat sampah yang cukup, halaman sekolah yang hijau penuh pepohonan.

Warga sekolah sangat mendukung tentang kebersihan sekolah baik dari kepala sekolah, ibu kantin, dan penjaga kebersihan. Kepala sekolah sangat mendukung serta mengajak juga memotivasi guru dan siswa lalu menyadarkan bahwa betapa pentingnya arti kebersihan kemudian ada program-program tentang kebersihan. Dukungan dari petugas kebersihan sangat membantu sekali karena mereka setiap hari melaksanakan kebersihan dihalaman sekolah, ruang kantor, dan taman. Dukungan dari kantin dengan menjaga kantin kemudian ketika anak-anak berbelanja, ibu kantin juga menghimbau kepada anak-anak untuk membuang sampah pada tempatnya karena di depan kantin sudah disediakan dua kotak sampah. Dan ketika sampahnya penuh baru di bawa di pembuangan akhir. Hal ini sesuai dengan penelitian (Anwari, 2014: 243) kegiatan spontan tersebut dapat berupa ajakan/memotivasi untuk selalu menjaga kebersihan lingkungan dan dapat pula bersifat peringatan atau teguran ketika terdapat perilaku siswa yang belum mencerminkan kepedulian terhadap lingkungan.

\section{Simpulan}

Berdasarkan hasil penelitian dapat disimpulkan bahwa sekolah Alam Mahira Kota Bengkulu secara umum telah menanamkan nilai-nilai kepedulian lingkungan yang bersih pada siswa kelas III melalui:

a. Strategi penanaman nilai-nilai kepedulian pada anak dilakukan dengan dengan 3 cara yakni : 1) Pembiasaan 2) Keteladanan 3) Mengajarkan tentang kebersiha.

b. Program-program kegiatan penananaman nilai-nilai kepedulian terhadap kebersihan lingkungan terdiri dari 4 program kegiatan, yakni : 1) Budaya bersih; 
2) Program sabtu bersih; 3) Kebersihan kelas dan kebersihan lingkungan sekolah; 4) Pengelolaan sampah.

c. Sarana dan prasarana yang dijadikan untuk mendukung kebersihan seperti: sarana yang disediakan sapu, kotak sampah, sapu lidi, sabun kamar mandi, sikat wc, pel, ember. Prasarana yang di sedikan air bersih, tempat cuci tangan, WC dan lain-lain.

d. Dukungan masyarakat sekolah terhadap penanaman nilai-nilai kepedulian sangat positif baik dari kepala sekolah, petugas kebersihan, ibu kantin dan warga sekolah lainnya.

\section{Saran}

Berdasarkan hasil penelitian dan pembahasan tentang bagaimana sekolah menanamkan nilai-nilai kepedulian lingkungan yang bersih. Peneliti menyarankan:

a. SD Alam Mahira disarankan mengadakan kembali program bank sampah. Agar sampah anorganik bisa didaur ulang dan sampah organik tersebut dapat dimanfaatkan sebagai pupuk yang berguna bagi sekolah.

b. Perlu digalakkan kegiatan kebersihan sekolah ini melalui slogan-slogan atau ajakan yang ditempelkan di dinding sekolah

c. Guru dan orangtua perlu bekerjasama untuk mendukung, mengawasi, hal yang menyangkut dengan kepedulian siswa terhadap kebersihan lingkungan baik di lingkungan sekolah maupun luar sekolah.

\section{Referensi}

Arikunto, S. 2013, Prosedur Penelitian Suatu Pendekatan Praktik. Jakarta: Rineka Cipta.

Anwari, A. 2014. Strategi Pembentukan Karakter Peduli Lingkungan Di Sekolah Adiwiyata Mandiri. Vol. XIX, nomor. 02, Hal: 233.

Desmita. 2012, Psikologi Perkembangan Peserta Didik. Bandung: Penerbit PT Remaja Rosdakarya.

Depdiknas. 2007. Pedoman Pembelajaran Bidang Pengembangan Pembiasaan Di Taman Kanak-kanat. Jakarta: Penerbit Depertemen Pendidikan Nasional.

Hamzah, S. 2013. Pendidikan Lingkungan. Bandung. Penerbit: PT Retika Aditama.

Kurniawan, S. 2016. Pendidikan Karakter. Yogyakarta: Penerbit Ar- Ruzz Media.

Kompri. 2014. Manajemen Sekolah Teori dan Praktik. Bandung: Penerbit Alfabeta.

Mundiatun \& Daryanto. 2015. Pengelolaan Kesehatan Lingkungan. Yogyakarta: Penerbit: Gava Media.

Samani, M. \& Harianto. 2011. Konsep dan Model Pendidikan Karakter. Surabaya: Penerbit Rosda.

Sumantri, A. 2015. Kesehatan Lingkungan (Edisi-3), Jakarta: Penerbit Kencana.

Sugiyono. 2014. Metode Penelitian Kuantitatif, Kualitatif dan $R \&$ D. Bandung: Penerbit Alfabeta.

2016. Memahami Penelitian Kualitatif. Bandung: Penerbit Alfabeta. 
Wakhidah, K. 2014. Pengaruh Penanaman Nilai-Nilai Konservasi Terhadap Karakter Peduli Pada Lingkungan Anak Usia Dini. Journal Unnes. Vol. 3 nomor. 2, Hal: 39-40.

Widiasworo, E. 2017. Masalah-Masalah Peserta Didik Dalam Kelas Dan Solusinya, Yogyakarta: Penerbit Araska Publisher.

Winarni, E., W. 2011. Penelitian Pendidikan, Bengkulu: FKIP Universitas Bengkulu.

Wulandari, R. 2016. Metode Kunjungan Lapangan Untuk Menanamkan Kepedulian Terhadap Lingkungan Hidup. Jurnal Pedagogia. Vol. 5, nomor. 1, Hal: 74. 